\title{
About Muddy Cyclists
}

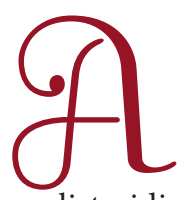

I read with amusement in a recent Europhysics News the witty piece by Jo Hermans about Muddy Cyclists [1], discus-

sing about the critical speed when a cyclist, riding on a muddy road, is spattered by mud detaching from his back wheel. He quotes a calculation by Fokke Tuinstra, yielding a value of $12 \mathrm{~km} / \mathrm{h}$, assuming a cycle of standard size, evidently without mudguard. It is interesting to note that cycling and cycles are a favourite among physicists - the dynamic equilibrium is a fascinating problem, and a dangerous one for the apprentice cyclist. I happened to make a brief bibliographical search about cycling scientists. The most prominent is Zéphyrin Brioché, alias "le savant Cosinus" [2] in the famous "L'idée fixe du savant

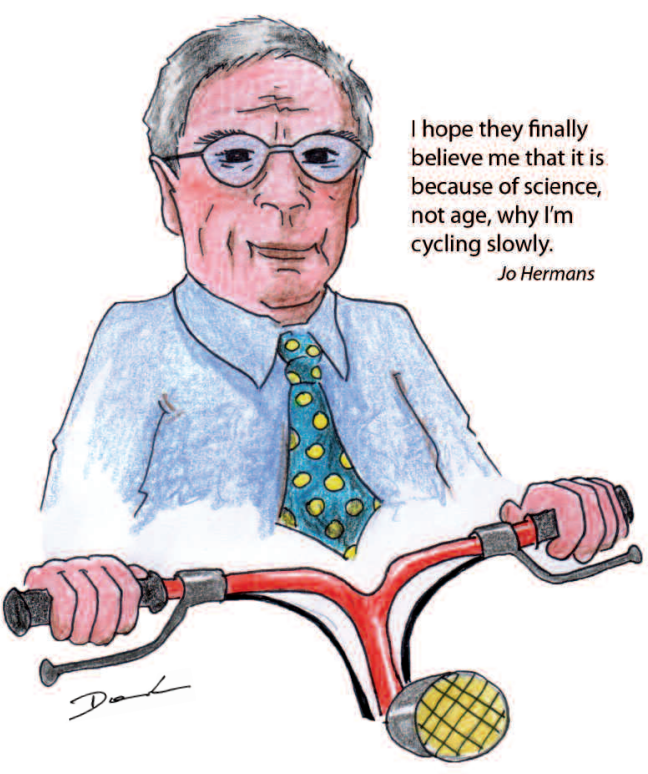

created the "anémoélectroreculpédalicoupeventombrosoparacloucycle", a multipurpose device which, beyond its cycling capabilities, included many other tools making it a forerunner of our modern mobile phones. Pursuing my quests, with the help of Google, I came upon an article by Henri Bouasse (1866-1953), in one of the 45 volumes of his "Traité de Physique" published at the turn of the $\mathrm{XX}^{\text {th }}$ century. Bouasse, physics professor at the University of Toulouse, was famous among physics students of my generation for his polemical prefaces, dealing aggressively with every possible subject, especially "modern" physics.

In a volume of Mechanics, one can find, under the title "le Problème du cycliste crotté" [3] the detailed derivation of the critical speed for the muddy cyclist. Bouasse arrived at a value of Cosinus", an excellent initiation to the psychosociology of scientists. After many unsuccessful theoretical attempts to formalize the cycle equilibrium, Cosinus

\section{Coming soon:}

\section{"physics of daily life" as a booklet}

Jo Hermans, passionate cyclist and author of the "Physics in daily life" column since 2003, has decided to take a well-deserved break from explaining to us the miracles of our daily surroundings. However, this page will remain dedicated to aspects of physics (and physicists) which make you smile and/or think! And those of you who have taken to the habit of browsing Jo's column will be relieved to hear that EDPS will soon bring out his texts, along with the illustrations by W. Drenckhan, as a handy booklet!
$12.64 \mathrm{~km} / \mathrm{h}$, same as found later by Tuinstra. "Rien de neuf sous le soleil", discoveries are often re-discoveries, the same problem can be studied again and again, when coming to the attention of curious minds.

In addition, for those interested in the connection between science and velocipedes, I cannot resist recommending the charming book by Sebastien Balibar [4], where among other things, he relates his experiences as a cycling physicist.

\section{References}

[1] L.J.F. (Jo) Hermans, "Physics in daily life: Muddy cyclists", Europhysics News 41-4, p. 29 (2010)

[2] Christophe (Georges Colomb), "L'idée fixe du savant Cosinus" (Armand Colin, Paris 1893, reprinted by Livre de Poche 1965). Fac-simile at http://aulas.pierre.free.fr/chr_cos_01.html

[3] http://melusine.eu.org/syracuse/mluque/bouasse/ disqueBouasseT.pdf

[4] Sébastien Balibar, "Je casse de l'eau et autres rêveries scientifiques", Le Pommier, Paris 2008 